\title{
Implementasi Kebijakan Layanan Pembebasan Biaya Perkara Hukum Bagi Masyarakat Tidak Mampu Di Pengadilan Agama Purwakarta Tahun 2017
}

\section{Implementation of Law Of Civil Service Policy Service For Public Religion In Purwakarta 2017}

\author{
Engkus ${ }^{1}$, Rudi Nasrudin ${ }^{2}$ \\ 1-2UIN Sunan Gunung Djati Bandung \\ Jln. A.H. Nasution 105, Bandung, 40614 \\ *Corresponding author E-mail : engkus@uinsgd.ac.id
}

Diterima: 11 November 2019 ; Direvisi: 3 Desember 2019 ; Disetujui: 4 Desember 2019

\begin{abstract}
ABSTRAK
Indonesia merupakan negara hukum yang mengakui dan melindungi Hak Asasi Manusia (HAM) pada setiap orang baik individu maupun kelompok tanpa mendiskriminasi ras, agama, suku, ekonomi, sehingga semua orang berhak mendapatkan pelayanan yang sama di mata hukum. Permasalahan yang diteliti adalah implementasi kebijakan Peraturan Mahkamah Agung Republik Indonesia Nomor 1 Tahun 2014 tentang Pedoman Pemberian Layanan Hukum Bagi Masyarakat Tidak Mampu di Pengadilan Agama Purwakarta tahun 2017, tujuan penelitian ini adalah ingin mengetahui tentang implementasi kebijakan layanan pembebasan biaya perkara serta kendala dan upaya untuk mengatasi kendala yang terjadi dalam implementasi kebijakan layanan pembebasan biaya perkara di Pengadilan Agama Purwakarta.Jenis penelitian ini merupakan penelitian kualitatif dengan pendekatan deskriptif. Data diambil dari dua sumber yaitu sumber primer dan sumber data sekunder. Metode pengumpulan data menggunakan observasi terhadap layanan pembebasan biaya perkara yang dijadikan sebagai data awal, wawancara dengan pihak berkompeten dalam bidang layanan pembebasan biaya perkara, dan studi dokumentasi ialah data yang diperoleh melalui bahan kepustakaan yang berhubungan tentang implementasi kebijakan layanan pembebasan biaya perkara kemudian data dianalisis secara kualitatif. Berdasarkan hasil penelitian, implementasi kebijakan Peraturan Mahkamah Agung Republik Indonesia Nomor 1 Tahun 2014 tentang Pedoman Pemberian Layanan Hukum Bagi Masyarakat Tidak Mampu di Pengadilan Agama Purwakarta tahun 2017 sudah sesuai dengan aturan Mahkamah Agung yang tercantum, tetapi dalam pelaksanaannya adanya faktor kendala yang terletak pada sistem penyampaian informasi berbasis internet yang tidak tepat untuk masyarakat tidak mampu, sumber daya staf yang double job, anggaran dan kuota layanan pembebasan biaya perkara yang terbatas yang menimbulkan layanan tidak merata di kalangan masyarakat tidak mampu.
\end{abstract}

Kata Kunci: Implementasi, Kebijakan, Pelayanan. 


\begin{abstract}
Indonesia is a legal state that recognizes and protects human rights in every person, both individuals and groups, without discriminating against race, religion, ethnicity, economy, so that all people have the right to receive the same service in the eyes of the law. The problems studied were the implementation of the Republic of Indonesia Supreme Court Regulation No. 1 of 2014 concerning Guidelines for Providing Legal Services for the Unable in the Pengadilan Agama Purwakarta in 2017, the purpose of this research was to know and know about implementation the case fee waiver service policy and the obstacles and efforts to overcome the obstacles that occur in the implementation of the case fee waiver service policy in the Pengadilan Agama Purwakarta. This type of research is qualitative research with a descriptive approach. Data is taken from two sources, namely primary sources and secondary data sources. The method of collecting data uses observations on case fee exemption services that are used as preliminary data, interviews with competent parties in the field of case fee waiver services, and documentation studies are data obtained through libraries related to the implementation of case fee waiver service policies, and then the data are analyzed qualitatively. Based on the results of the study, the implementation of the Republic of Indonesia's Supreme Court Regulation No. 1 of 2014 concerning Guidelines for Providing Legal Services for the Unable in the Pengadilan Agama Purwakarta in 2017 by the rules of the Supreme Court, but its implementation here is an obstacle factor that lies in the internet-based information delivery system that is not appropriate for poor people, staff resources that are double jobs, budget and limited quota fee exemption services that lead to uneven services among the poor.
\end{abstract}

Keywords: Implementation, Policy, Service.

\title{
PENDAHULUAN
}

David Easton mengungkapkan bahwa kebijakan publik merupakan pengalokasian nilai-nilai secara sah/ paksa kepada sejumlah masyarakat. Kebijakan Masyarakat Indonesia bukan merupakan masyarakat yang sejahtera dalam segala bidang. Bahkan dapat dikatakan bahwa masyarakat belum mencapai tingkat kemerdekaan yang sebenarnya, mengingat banyak hal yang terjadi pada saat ini. Negara Indonesia adalah suatu negara hukum, sudah selayaknya hak perlindungan hukum dengan segala kemudahannya menjadi hak yang dapat diterima semua lapisan masyarakat dalam waktu yang berkesinambungan, artinya adalah tanpa batas waktu (Anggraini, 2018). Ketika di negara hukum ini, perlindungan hukum sudah tidak bisa ditembus oleh masyarakat kurang mampu, maka identitas negara Indonesia sebagai negara hukum, patut dipertanyakan kembali kelayakan memiliki identitas 
tersebut.

Seperti kemiskinan, yang ditimbulkan dari banyaknya pengangguran dan berakibat pada ketidakmampuan masyarakat membayar keperluan dalam kehidupannya. Menurut data yang diperoleh dari Badan Pusat Statistik Provinsi Jawa Barat, angka kemiskinan pada tahun 2017 mengalami peningkatan dari 4.168,11 Ribu Jiwa menjadi 4.168,44 Ribu Jiwa terhitung pada bulan Maret 2017 (Alwasyi, 2019).

Layanan hukum tersebut harus diberikan secara maksimal oleh pihak berwenang tanpa memperhatikan kesanggupan masyarakat dalam segi pembayarannya. Pengadilan Agama (PA) Purwakarta merupakan Lembaga Peradilan tingkat pertama yang berwenang mengadili perkara yang menjadi kewenangan Badan Peradilan Agama dalam tingkat pertama yang berhubungan langsung dengan masyarakat di wilayah hukum Kabupaten Purwakarta. Dan dalam hal ini, bersangkutan dengan pemaparan di atas, bahwa tidak semua masyarakat yang terlibat suatu perkara memiliki kemampuan dalam pembayaran jasa tersebut, kinerja organisasi di Pengadilan Agama (PA) Purwakarta juga perlu diperhatikan, agar tidak menimbulkan kinerja yang buruk. Pegawai harus sadar akan posisi organisasinya sebagai organisasi publik yang berorientasi manfaat dan bukan keuntungan. Pada hakikatnya, organisasi publik tidak berorientasi pada keuntungan, justru seharusnya yang menjadi orientasinya adalah manfaat dari organisasi tersebut.

Dalam Peraturan Mahkamah Agung RI Nomor 1 Tahun 2014 tentang Pedoman Pemberian Layanan Hukum Bagi Masyarakat Tidak Mampu di Pengadilan, meliputi Layanan Pembebasan Perkara, Sidang di Luar Gedung Pengadilan, dan Posbakum Pengadilan di Lingkungan Peradilan Umum, Peradilan Agama dan Peradilan Tata Usaha Negara.

Menurut Peraturan Mahkamah Agung Republik Indonesia Nomor 1 Tahun 2014 tentang Pedoman Pemberian Layanan Hukum Bagi Masyarakat Tidak Mampu di Pengadilan Pasal 1 bahwa Layanan Pembebasan Biaya 
Perkara berlaku pada tingkat pertama, tingkat banding, tingkat kasasi dan peninjauan kembali, sementara Sidang di Luar Pengadilan dan Posbakum Pengadilan hanya berlaku pada tingkat pertama.

Begitupula dalam penelitian ini memfokuskan pada BAB III tentang Layanan Pembebasan Biaya Perkara atau disebut juga Prodeo yang terdiri dari Pasal 7, 8, 9, 10, 11, 12, dan 13. Layanan Pembebasan Biaya Perkara (Prodeo) adalah negara yang menanggung biaya proses berperkara di Pengadilan sehingga setiap orang atau sekelompok orang yang tidak mampu secara ekonomi dapat berperkara secara cuma-cuma.

Berdasarkan Pasal 11 ayat (1) Peraturan Mahkamah Agung Nomor 1 Tahun 2014 tentang Pedoman Pemberian Layanan Hukum Bagi Masyarakat Tidak Mampu di Pengadilan, yang termasuk dalam Komponen Pembebasan biaya perkara adalah sebagai berikut:

Komponen biaya sebagai akibat dari pembebasan biaya perkara terdiri dari : a). Materai; b). Biaya Pemanggilan para pihak; c). Biaya Pemberitahuan Isi Putusan; d). Biaya Sita Jaminan; e). Biaya Pemeriksaan setempat; f).Biaya Saksi/Ahli; g). Biaya eksekusi; h). Alat Tulis Kantor (ATK);i).Penggandaan/foto copy berkas perkara dan surat-surat yang berkaitan dengan berkas perkara ; j).Penggandaan salinan putusan; k).Pengiriman pemberitahuan nomor register ke Pengadilan Pengaju dan para pihak, salinan putusan, berkas perkara dan surat-surat lain yang dipandang perlu; l). Pemberkasan dan penjilidan berkas perkara yang telah diminutasi; dan; m). Pengadaan perlengkapan kerja Kepaniteraan yang habis pakai.

Sementara menurut data sasaran strategis di Pengadilan Agama Purwakarta pada tahun 2017 layanan hukum bagi masyarakat tidak mampu mengenai penyelesaian perkara Pembebasan Biaya Perkara (Prodeo) tidak mencapai prosentase target yang ditentukan (PN-Purwakarta, 2014). Hal ini juga menunjukan bahwa akses masyarakat untuk mendapatkan Layanan Hukum masih tidak akan mencapai kepuasaan yang maksimal.

Sasaran strategis Pengadilan Agama Purwakarta yang 
mengimplementasikan kebijakan Peraturan Mahkamah Agung Republik Indonesia Nomor 1 Tahun 2014 tentang Pedoman Pemberian Layanan Hukum Bagi Masyarakat Tidak Mampu di Pengadilan , mengenai meningkatnya akses peradilan bagi masyarakat miskin dan terpinggirkan dengan rincian sebagai berikut pada tabel 1 .

Tabel 1. Capaian Kinerja Layanan Hukum Bagi Masyarakat Tidak Mampu di Pengadilan Agama Purwakarta Tahun 2017

\begin{tabular}{|c|c|c|c|}
\hline \multirow{2}{*}{$\begin{array}{l}\text { SASARAN } \\
\text { STRATEGIS }\end{array}$} & \multicolumn{3}{|c|}{ INDIKATOR KINERJA } \\
\hline & URAIAN & TARGET (\%) & REALISASI (\%) \\
\hline \multirow{3}{*}{$\begin{array}{l}\text { Meningkatnya } \\
\text { akses peradilan } \\
\text { bagi masyarakat } \\
\text { miskin dan } \\
\text { terpinggirkan }\end{array}$} & $\begin{array}{l}\text { Prosentase perkara prodeo } \\
\text { yang diselesaikan }\end{array}$ & 100 & 93,33 \\
\hline & $\begin{array}{lcc}\text { Prosentase } & \text { perkara } & \text { yang } \\
\text { diselesaikan } & \text { di } & \text { luar } \\
\text { pengadilan } & & \\
\end{array}$ & 100 & 100 \\
\hline & $\begin{array}{l}\text { Prosentase } \\
\text { keadilan golongan tertentu } \\
\text { yang mendapat Layanan } \\
\text { Bantuan Hukum (Posbakum) } \\
\text { yang diselesaikan }\end{array}$ & 100 & 99,98 \\
\hline
\end{tabular}

Sumber : LKJIP Pengadilan Agama Purwakarta 2017

Data tersebut menunjukan bahwa kinerja Pengadilan Agama

Purwakarta dalam mengimplementasikan kebijakan Peraturan Mahkamah Agung Republik Indonesia Nomor 1 Tahun 2014 tentang Pedoman Pemberian Layanan Hukum Bagi Masyarakat Tidak Mampu di Pengadilan pada tahun 2017 khususnya penyelesaian perkara prodeo atau pembebasan biaya perkara tidak maksimal. Pada tahun 2017 Pengadilan Agama (PA) Purwakarta menangani 14 perkara prodeo, dengan beban perkara sebanyak 15 perkara, Pengadilan Agama Purwakarta berhasil menyelesaikan sebanyak 14 perkara, sehingga realisasi penyelesaian perkara prodeo sebesar 14 Perkara. Dengan target untuk indikator perkara prodeo yang diselesaikan adalah sebesar 100\%, maka capaiannya adalah sebesar 93,33\%. Per 31 Desember 2017 tersisa 1 perkara prodeo yang tidak dilaksanakan.

Di samping berperkara secara cuma-cuma (prodeo murni), layanan pembebasan biaya perkara juga diberikan melalui DIPA (Daftar Isian Pengeluaran Anggaran) Pengadilan Agama Purwakarta sepanjang 
ketersediaan anggaran. Dari 15 perkara prodeo yang diterima pada tahun 2017 sebanyak 14 perkara dibebankan kepada DIPA Pengadilan Agama Purwakarta tahun 2017 dengan total anggaran sebesar Rp. 5.250.000,- (lima juta dua ratus lima puluh ribu rupiah) dan telah direalisasikan sebesar 86,67\% yaitu Rp. 4.900.000 dengan sisa anggaran sebesar Rp. 350.000, sebagaimana rincian DIPA No.005.01.0200.400855 berikut ini:

Tabel 2. DIPA (Daftar Isian Pengeluaran Anggaran) Pengadilan Agama Purwakarta

\begin{tabular}{|l|c|c|c|}
\hline \multirow{2}{*}{ URAIAN } & \multicolumn{3}{|c|}{ 31 DESEMBER 2017 } \\
\cline { 2 - 4 } & Pagu & Realisasi & Presentase \\
\hline & (Rp) & (Rp) & $\%$ \\
\hline $\begin{array}{l}\text { Perkara di lingkungan Peradilan } \\
\text { Agama yang Diselesaikan Melalui } \\
\text { Pembebasan Biaya Perkara }\end{array}$ & 5.250 .000 & 4.900 .000 & 93,33 \\
\hline
\end{tabular}

Sumber : LKJIP Pengadilan Agama Purwakarta 2017

Hal ini juga ditunjukan dari index responden pencari keadilan yang puas terhadap layanan peradilan yang tidak mencapai target yang ditentukan 100\% sebagaimana data berikut:

Tabel 3. Index Responden Pencari Keadilan Tentang Kepuasan Masyarakat

\begin{tabular}{|c|c|c|c|}
\hline \multicolumn{4}{|c|}{ INDIKATOR KINERJA } \\
\hline \multicolumn{1}{|c|}{ URAIAN } & TARGET (\%) & REALISASI (\%) & \% \\
\hline $\begin{array}{l}\text { Index Responden Pencari Keadilan } \\
\text { yang Puas terhadap Layanan } \\
\text { Peradilan }\end{array}$ & 100 & 95 & 95 \\
\hline
\end{tabular}

Sumber : LKJIP Pengadilan Agama Purwakarta 2017.

Data yang ditunjukan di atas dapat dikatakan sudah baik, akan tetapi tidak tercapainya suatu target tidak akan terjadi tanpa sebab, oleh karena itu 5\% yang tidak tercapai tersebut menjadi point penting untuk menunjang dan menunjukan bahwa implementasi kebijakan Peraturan Mahkamah Agung Republik Indonesia Nomor 1 Tahun 2014 tentang Pedoman Pemberian Layanan Hukum Bagi Masyarakat Tidak Mampu di Pengadilan pada tahun 2017 khususnya penyelesaian perkara prodeo atau pembebasan biaya perkara masih harus ditingkatkan guna tercapainya kepuasan masyarakat atas layanan hukum cuma-cuma secara maksimal.

Layanan Hukum bagi masyarakat tidak mampu ataupun masyarakat terpinggirkan ini akan didapatkan secara mudah dan menghasilkan pelayanan 
publik yang akan mendapatkan pengakuan rasa puas dari masyarakat sasaran. Dalam hal ini juga masyarakat menjalankan kehidupannya dengan tenang dan aman di bawah perlindungan hak hukumnya tanpa harus khawatir atas ketidakmampuannya membayar layanan hukum yang dibutuhkannya. Seharusnya, dengan adanya prosedur yang ditetapkan oleh Pengadilan Agama Purwakarta tersebut menjadikan kinerja pegawai Pengadilan Agama Purwakarta bisa disesuaikan dengan Standard Operational Procedure (SOP) yang dimaksimalkan pelaksanaannya.

Berpedoman Peraturan Mahkamah Agung Republik Indonesia Nomor 1 Tahun 2014 tentang Pedoman Pemberian Layanan Hukum Bagi Masyarakat Tidak Mampu di Pengadilan, ini artinya adalah bahwa layanan hukum ini bersifat wajib untuk diberikan kepada masyarakat tidak mampu, keadilan yang seharusnya menjadi hak masyarakat tidak bisa disandingkan dengan keuangan.

\section{METODE PENELITIAN}

Metode penelitian menurut Darmawan adalah cara yang digunakan oleh peneliti untuk mendapatkan data dan informasi mengenai berbagai hal yang berkaitan dengan masalah yang diteliti (Darmawan, 2013). Istilah metode, berasal dari kata methodos (Yunani) berarti cara atau jalan. Berkaitan dengan upaya ilmiah, metode dihubungkan dengan cara kerja, yaitu cara kerja untuk dapat memahami objek yang menjadi sasaran ilmu yang bersangkutan. Istilah metodologi menunjuk pada proses, prinsip serta prosedur yang digunakan untuk mendekati masalah dan mencari jawaban atas masalah tersebut.

Pada hakikatnya penelitian kualitatif ini melakukan penelitian dalam keadaan alamiah, untuk itu data dan informasi yang dikumpulkan juga bersifat kualitatif. Begitu pula Sugiyono mengungkapkan bahwa metode penelitian kualitatif ialah Metode penelitian yang digunakan untuk meneliti pada kondisi obyek yang alamiah, (sebagai lawannya adalah eksperimen) di mana peneliti adalah sebagai instrumen kunci, teknik pengumpulan data dilakukan secara triangulasi (gabungan), analisis data bersifat induktif, dan hasil penelitian 
kualitatif lebih menekankan makna daripada generalisasi (Sugiyono, 2013).

Moleong mengungkapkan bahwa penelitian kualitatif adalah Penelitian yang bermaksud untuk memahami fenomena tentang apa yang dialami oleh subjek penelitian misalnya perilaku, persepsi, motivasi, tindakan baik secara holistik dengan cara dekripsi dalam bentuk kata-kata dan bahasa, pada suatu konteks khusus yang alamiah dan dengan memanfaatkan berbagai metode alamiah (Moleong, 2011).

Metode penelitian yang digunakan oleh peneliti adalah metode kualitatif dengan pendekatan deskriptif. Sebagaimana yang digunakan dalam penelitian ini adalah pendekatan deskriptif menurut Nurul Zuriah sebagai Pendekatan deskriptif adalah pendekatan yang diarahkan untuk memberikan gejala-gejala, fakta-fakta, atau kejadian-kejadian secara sistematis dan akurat mengenai sifat-sifat populasi maupun daerah tertentu. Dalam penelitian deskriptif tidak bermaksud untuk menguji hipotesis, tetapi menggambarkan apa adanya tentang suatu variabel, gejala atau keadaan (Anggara, 2018).

Selanjutnya Sugiyono mendefinisikan penelitian deskriptif ialah "Penelitian yang dilakukan untuk mengetahui nilai variabel mandiri, baik satu variabel atau lebih (independen) tanpa membuat perbandingan, atau menghubungkan antara variabel satu dengan variabel yang lain." Kemudian Whitney mengungkapkan bahwa pendekatan deskriptif ialah Pencarian fakta dengan intervensi yang tepat (Nazir, 2014).

Begitupula dalam penelitian ini bermaksud untuk mencari tahu nilai variabel dari Implementasi Kebijakan Peraturan Mahkamah Agung Republik Indonesia Nomor 1 Tahun 2014 tentang Pedoman Pemberian Layanan Hukum Bagi Masyarakat Tidak Mampu di Pengadilan Agama Purwakarta (Studi pada Layanan Pembebasan Biaya Perkara) Tahun 2017.

\section{TEMUAN DAN PEMBAHASAN}

Implementasi kebijakan Peraturan Mahkamah Agung Republik Indonesia Nomor 1 Tahun 2014 tentang Pedoman Pemberian Layanan Hukum Republik Indonesia Bagi Masyarakat Tidak Mampu di Pengadilan Agama Purwakarta (Studi pada Layanan Pembebasan Biaya Perkara) pada tahun 
2017. Pada proses kebijakan publik, implementasi kebijakan sebagai tahapan yang sangat penting dari keseluruhan siklus dari kebijakan publik. Implementasi kebijakan adalah kegiatan yang dilakukan setelah suatu kebijakan dirumuskan dengan sangat matang.

Peraturan Mahkamah Agung Republik Indonesia Nomor 1 Tahun 2014 tentang Pedoman Pemberian Layanan Hukum Bagi Masyarakat Tidak Mampu di Pengadilan Agama Purwakarta (Layanan Pembebasan Biaya Perkara) adalah program Mahkamah Agung yang harus dilaksanakan di setiap Pengadilan seluruh Negara Kesatuan Republik Indonesia, baik Pengadilan Negeri, Pengadilan Agama serta Pengadilan Tinggi.

Dalam hal ini di Pengadilan Agama (PA) Purwakarta, tujuan kebijakan tersebut adalah meningkatkan akses bagi para pencari keadilan dengan ringan biaya dan meningkatkan kesadaran masyarakat pentingnya memanfaatkan layanan hukum yang disediakan oleh pemerintah bagi masyarakat tidak mampu di lingkungan Kabupaten Purwakarta (Ishak, Maolani, \& Engkus, 2017).

Pengadilan Agama (PA) Purwakarta telah melaksanakan kebijakan Peraturan Mahkamah Agung Republik Indonesia Nomor 1 Tahun 2014 tentang Pedoman Pemberian Layanan Hukum Bagi Masyarakat Tidak Mampu di Pengadilan Agama Purwakarta (Studi pada Layanan Pembebasan Biaya Perkara) pada tahun 2017 dengan berpedoman pada SOP (Standar Operasional Prosedur) yang berlaku (Engkus, 2017).

Dari 4 (empat) dimensi Edward III yang turut berpengaruh dalam implementasi kebijakan masing-masing dimensi masih mengalami hambatan dari masing-masing indikatornya. Kendati demikian, pada dimensi komunikasi indikator kejelasan informasi dan konsistensi informasi sudah dapat dikatakan baik dalam pelaksanaanya, pada indikator transmisi yang masih mengalami hambatan. Selanjutnya pada dimensi sumber daya yang masih dapat dikatakan kurang pada indikator staf, informasi dan fasilitas, tetapi pada indikator wewenang dapat dikatakan sudah baik pelaksanaanya. 
Kemudian pada dimensi disposisi indikator penempatan pegawai sudah baik, hanya saja kekurangan ada pada indikator insentif. Selanjutnya dimensi struktur birokrasi ini yang menjadi point penting, pada indikator SOP (Standar Operasional Prosedur) telah dilaksanakan dengan baik, akan tetapi pada indikator fragmentasi masih terjadi kesalahan yang cukup besar dalam proses implementasinya masih ditemukan beberapa masalah, seperti yang ditemukan oleh peneliti ketika melakukan wawancara dengan pegawai Pengadilan Agama (PA) Purwakarta sebagai informan yang peneliti telah pilih.

Sementara itu, kendala Implementasi Kebijakan Peraturan Mahkamah Agung Republik Indonesia Nomor 1 Tahun 2014 tentang Pedoman Pemberian Layanan Hukum Bagi Masyarakat Tidak Mampu di Pengadilan Agama Purwakarta (Studi pada Layanan Pembebasan Biaya Perkara) tahun 2017 apabila dilihat dari dimensi Komunikasi terdapat masalah seperti tidak adanya komunikasi secara langsung (sosialisasi) yang dilakukan Pengadilan Agama (PA) Purwakarta terhadap masyarakat di Kabupaten Purwakarta tentang adanya suatu kebijakan yang akan membantu meringankan dan memudahkan masyarakat tidak mampu untuk mendapatkan layanan hukum dalam ruang lingkup Pengadilan Agama.

Berikut hasil wawancara peneliti dengan Masyarakat Desa Cipeundeuy Kecamatan Bojong Kabupaten Purwakarta :

“Tetep ya saya menekankan pada kejelasan informasi yang sebenarnya itu seperti apa dan disampaikan secara langsung, secara lebih dekat lah yah kepada masyarakat, dan harus dapat memastikan bahwa informasi mengenai kebijakan Peraturan Mahkamah Agung Republik Indonesia Nomor 1 Tahun 2014 tentang Pedoman Pemberian Layanan Hukum Bagi Masyarakat Tidak Mampu di Pengadilan Agama Purwakarta (Layanan Pembebasan Biaya Perkara) tersebut sampai di kalangan masyarakat secara luas, terutama masyarakat dalam kategori tidak mampu."

Sementara ditinjau dari dimensi Sumber Daya, setelah peneliti melaksanakan wawancara dengan Masyarakat Desa Cipeundeuy Kecamatan Bojong Kabupaten Purwakarta bahwa ditemukan masalah yang sesuai dengan yang disampaikan oleh Ketua dan Staf Panitera yang sekaligus merupakan bahwa "sumber daya fasilitas kurang, ketika informasi saja tidak diterima dengan baik oleh masyarakat, maka ada kurang dalam fasilitas yang diberikan 
oleh pihak berwenang tentang kebijakan tersebut."

Hal tersebut tidak dapat memberikan keadilan bagi masyarakat sasaran, yaitu masyarakat tidak mampu yang membutuhkan pelayanan hukum secara cuma-cuma atau disebut layanan prodeo.

Berdasarkan hasil wawancara peneliti dengan Staf Panitera bahwa sumber daya fasilitas anggaran pun memiliki peran yang sangat penting di dalam implementasi kebijakan tersebut adalah sebagai berikut :

"Di samping kita ini memiliki atau mendapatkan anggaran yang hanya untuk membiayai 3 perkara saja setiap bulannya, maka ketika saya di pelayanan meja 1 dibuat strategi bahwa ketika dibulan januari 3 perkara sudah terpenuhi dan masih ada yang membuat permohonan prodeo, maka perkara yang lebih dari 3 tersebut dimasukan ke periode Februari."

Dengan kondisi demikian, maka akan menjadi beban bagi bulan anggaran selanjutnya, di mana jatah yang tersisa pada bulan tersebut hanya 2 perkara saja.

Ditinjau dari dimensi disposisi bahwa di Pengadilan Agama (PA) Purwakarta, penempatan pegawai sudah baik, begitu pula implementasi kebijakan Peraturan Mahkamah Agung Republik Indonesia Nomor 1 Tahun 2014 tentang Pedoman Pemberian Layanan Hukum Bagi Masyarakat Tidak Mampu di Pengadilan Agama Purwakarta (Layanan Pembebasan Biaya Perkara) yang sudah ditentukan petugas-petugas yang melaksanakannya, untuk indikator insentif menurut Staf Panitera dari hasil wawancara bersama peneliti, menyatakan bahwa :

"Semua instansi sama Sri Mulyani akan diberi anggaran DIPA (Daftar Isian Pengeluaran Anggaran), itu nah dianggarkan akun-akun yang sudah disediakan kita harus bisa mengolahnya/ menyerapnya jangan sampai tidak terserap ataupun jangan sampai diserap tapi dikorupsi, pada 2017 kita hanya diberi anggaran untuk prodeo itu Rp. 5.250.000 dan cuma untuk 3 perkara saja."

Dengan anggaran demikian, maka peluang untuk insentif petugas tidak ada, apabila insentif dipaksakan ada, maka akan diidentifikasi sebagai perilaku korupsi, dan hal tersebut sangat tidak diharapkan.

Sementara itu dari dimensi Struktur Birokrasi, ada pada masalah paling fatal, pada indikator fragmentasi terdapat kelalaian yang dilakukan oleh petugas pelaksana kebijakan Peraturan Mahkamah Agung Republik Indonesia Nomor 1 Tahun 2014 tentang Pedoman Pemberian Layanan Hukum Bagi 
Masyarakat Tidak Mampu di Pengadilan Agama Purwakarta (Layanan Pembebasan Biaya Perkara), yang tidak menyelesaikan satu perkara disebabkan oleh tidak baiknya kerjasama dan komunikasi yang dijalin. Serupa dengan yang disampaikan oleh Staf Panitera Pengadilan Agama (PA) Purwakarta dari hasil wawancara dengan peneliti, bahwa :

"Pada 2017 itu ada satu yang tidak diselesaikan, karena miskomunikasi kitu lah, anggaran dikira sekretaris habis, di akhir tahun bidang keuangan bilang masih ada satu jatah, mau diselesaikan udah ga ada waktu"

Kejadian seperti demikian merugikan masyarakat yang perkaranya tidak diselesaikan pada tahun tersebut. Kerja sama pada hakikatnya mebutuhkan koordinasi yang baik dan tentunya jalinan komunikasi yang baik pula.

Kemudian upaya dalam menangani kendala Implementasi Kebijakan Peraturan Mahkamah Agung Republik Indonesia Nomor 1 Tahun 2014 tentang Pedoman Pemberian Layanan Hukum Bagi Masyarakat Tidak Mampu di Pengadilan Agama Purwakarta (Studi pada Layanan Pembebasan Biaya Perkara) Tahun 2017.

Untuk dapat mengatasi masalah pada dimensi Komunikasi terdapat masalah seperti tidak adanya komunikasi secara langsung (sosialisasi) yang dilakukan Pengadilan Agama (PA) Purwakarta terhadap masyarakat di Kabupaten Purwakarta tentang adanya suatu kebijakan yang akan membantu meringankan dan memudahkan masyarakat tidak mampu untuk mendapatkan layanan hukum dalam ruang lingkup Pengadilan Agama, upaya yang dilakukan dapat berupa memperbaiki sistem penyediaan informasi, dengan cara lebih sistem yang lebih pro terhadap tidak mampu dan kesulitan dalam mengakses internet.

Kemudian upaya yang dilakukan guna mengatasi masalah kurangnya sumber daya informasi yang diberikan Pengadilan Agama (PA) Purwakarta adalah dengan meningkatkan jumlah petugas pelaksana dan menghapuskan segala bentuk double job yang kemudian akan dengan otomatis memperbaiki kekurangan pada dimensi sumber daya informasi. Adapun masalah lain pada dimensi sumber daya ini ada pada indikator fasilitas, yaitu kurangnya fasilitas 
POLITICON : Jurnal Ilmu Politik Vol.1 No.2 ; Hal 175-192

Website : http://journal.uinsgd.ac.id/index.php/politicon ISSN : 2685-6670 ( Online )

anggaran untuk Implementasi Kebijakan Peraturan Mahkamah Agung Republik Indonesia Nomor 1 Tahun 2014 tentang Pedoman Pemberian Layanan Hukum Bagi Masyarakat Tidak Mampu di Pengadilan Agama Purwakarta (Studi pada Layanan Pembebasan Biaya Perkara) Tahun 2017 yang hanya diberikan jatah layanan 3 perkara saja setiap bulannya.

Sementara itu upaya yang dilakukan untuk menangani kendala tidak adanya insentif khsusus bagi petugas pelaksana pada dimensi disposisi, dapat menggunakan upaya peningkatan pemberian reward bagi petugas yang maksimal dalam menjalankan tugas dan wewenang yang diembannya untuk memberikan layanan secara cuma-cuma bagi masyarakat pencari keadilan dalam kategori tidak mampu.

Masalah kelalaian yang bersifat fatal dan berdampak pada tidak terselesaikannya suatu perkara karena murni adanya merupakan kesalahan pihak intansi atas kerjasama serta komunikasi yang kurang terjalin baik di lingkungan pegawai Pengadilan Agama (PA) Purwakarta pada dimensi struktur birokrasi indikator fragmentasi dapat diupayakan melalui lebih ditingkatkannya komunikasi dan kerjasama yang terjalin dan pengawasan dan pemeriksaan kembali secara ketat untuk semua aspek yang terlibat, baik anggarannya maupun kesiapan petugas menyelesaikan layanan hukum cumacuma ini.

Menyikapi situasi demikian diharuskan adanya upaya evaluasi bagi Mahkamah Agung Republik Indonesia sebagai pembuat kebijakan, guna meningkatkan keberhasilan implementasi kebijakan Implementasi Kebijakan Peraturan Mahkamah Agung Republik Indonesia Nomor 1 Tahun 2014 tentang Pedoman Pemberian Layanan Hukum Bagi Masyarakat Tidak Mampu di Pengadilan Agama Purwakarta (Studi pada Layanan Pembebasan Biaya Perkara) Tahun 2017 dengan didukung oleh sumber daya fasilitas anggaran yang harus ditingkatkan serta sumber daya pegawai yang perlu ditingkatkan jumlahnya (Lele, 2012).

\section{SIMPULAN}

Berdasarkan penelitian yang dilakukan oleh peneliti mengenai 
Implementasi Kebijakan Peraturan Mahkamah Agung Republik Indonesia Nomor 1 Tahun 2014 tentang Pedoman Pemberian Layanan Hukum Bagi Masyarakat Tidak Mampu di Pengadilan Agama Purwakarta (Studi pada Layanan Pembebasan Biaya Perkara) Tahun 2017, dari data-data yang telah diolah dan dianalisis oleh peneliti dalam penelitian ini, maka dapat disimpulkan sebagai berikut: (1).Implementasi Kebijakan Peraturan Mahkamah Agung Republik Indonesia Nomor 1 Tahun 2014 tentang Pedoman Pemberian Layanan Hukum Bagi Masyarakat Tidak Mampu di Pengadilan Agama Purwakarta (Studi pada Layanan Pembebasan Biaya Perkara) Tahun 2017 diukur menggunakan teori implementasi kebijakan Edward III, secara keseluruhan dapat dikatakan sudah dilaksanakan dengan baik seperti yang terjadi pada dimensi komunikasi indikator kejelasan informasi dan konsistensi informasi yang dilakukan sudah sangat baik karena tidak menimbulkan kesalahan persepsi ketika informasi tersebut diterima, akan tetapi pada indikator transmisi terlaksana kurang baik karena informasi yang disampaikan sampai dengan merata di kalangan masyarakat dan cara yang digunakan untuk memberikan informasi dinilai kurang tepat untuk masyarakat sasaran yang tergolong masyarakat tidak mampu, karena masyarakat tidak mampu tidak akan dapat dengan mudah menikmati pelayanan prima yang diberikan apabila hanya mengandalkan website resmi Pengadilan Agama (PA) Purwakarta. Kemudian pada dimensi sumber daya yang terjadi pada dimensi wewenang sudah baik karena dalam hal ini wewenang untuk melaksanakan implementasi sudah sesuai dengan SOP (Standar Operasional Prosedur) tetapi pada indikator staf yang mengalami double job, sumber daya informasi yang tidak merata tersampaikan di masyarakat tidak mampu Kabupaten Purwakarta dan sumber daya fasilitas anggaran yang mengalami keterbatasan. Sementara itu pada indikator Disposisi, indikator penempatan pegawai telah baik dilaksanakan karena berpedoman pada SOP, lain hal dengan indikator insentif yang belum maksimal dilakukan, kurang dalam memberikan reward pada petugas yang 
berhasil melaksanakan implementasi kebijakan tersebut. Begitu pula pada dimensi struktur birokrasi pada indikator fragmentasi, dengan hambatan ataupun kesalahan yang terjadi pada implementasi kebijakan Peraturan Mahkamah Agung Republik Indonesia Nomor 1 Tahun 2014 tentang Pedoman Pemberian Layanan Hukum Bagi Masyarakat Tidak Mampu di Pengadilan Agama Purwakarta (Studi pada Layanan Pembebasan Biaya Perkara) Tahun 2017 menunjukan bahwa kurangnya kerjasama antar pegawai di Pengadilan Agama (PA) Purwakarta, sementara pada indikator SOP sudah baik apabila melaksanakan sesuai aturan yang telah disediakan. Dalam hal ini masingmasing dimensi masih memiliki kendala-kendala yang berpengaruh banyak bagi kelangsungan proses implementasi tersebut. Pengadilan Agama (PA) Purwakarta juga selalu meningkatkan pelayanannya, akan tetapi kendalakendala masih dialami karena memang sosialisasi mengenai kebijakan tersebut tidak merata yang menjadi kuncinya. (2).Kendala-kendala dalam Implementasi Kebijakan Peraturan Mahkamah Agung Republik Indonesia Nomor 1 Tahun 2014 tentang Pedoman Pemberian Layanan Hukum Bagi Masyarakat Tidak Mampu di Pengadilan Agama Purwakarta (Studi pada Layanan Pembebasan Biaya Perkara) Tahun 2017 dengan menggunakan teori implementasi kebijakan Edward III, kendala tersebut pada dimensi komunikasi indikator transmisi adalah tidak meratanya informasi yang disampaikan oleh Pengadilan Agama (PA) Purwakarta, sehingga masih ada suatu daerah yang sama sekali tidak pernah tersentuh informasi mengenai kebijakan tersebut. Kemudian pada dimensi sumber daya indikator staf, informasi dan fasilitas, di mana kualitas staf sudah dapat dikatakan mumpuni, akan tetapi double job masih terjadi di Pengadilan Agama (PA) Purwakarta, sementara pada indikator fasilitas kendala yang terjadi adalah fasilitas yang diberikan masih kurang dikhususkan pada fasilitas finansial yang jauh dari kata cukup apabila hanya diberi jatah 3 (tiga) perkara perbulannya. Kemudian pada dimensi di posisi yang mengalami kendala adalah pada indikator insentif untuk petugas implementasi kebijakan itu sendiri yang tidak disediakan 
karena keterbatasan anggaran yang disediakan melalui DIPA (Daftar Isian Pengeluaran Anggaran). Terakhir ialah dimensi struktur birokrasi, yang mempunyai kendala dalam proses implementasi kebijakan Peraturan Mahkamah Agung Republik Indonesia Nomor 1 Tahun 2014 tentang Pedoman Pemberian Layanan Hukum Bagi Masyarakat Tidak Mampu di Pengadilan Agama Purwakarta (Studi pada Layanan Pembebasan Biaya Perkara) Tahun 2017 adalah indikator fragmentasi, pada indikator fragmentasi ini menitikberatkan pada kerjasama yang terjalin diantara pegawai Pengadilan Agama (PA) Purwakarta, baik yang menjadi petugas pemberi layanan hukum bagi masyarakat tidak mampu pembebasan biaya perkara, petugas posbakum (pos bantuan hukum) maupun petugas sidang keliling dengan pihak-pihak terkait dengan kebijakan tersebut. Dalam hal ini, kendalanya adalah kurangnya kerja sama yang terjalin, menyebabkan timbulnya terbengkalainya satu perkara yang tidak diselesaikan. Upaya untuk mengatasi kendala yang terjadi dalam implementasi kebijakan Peraturan Mahkamah Agung Republik Indonesia Nomor 1 Tahun 2014 tentang Pedoman Pemberian Layanan Hukum Bagi Masyarakat Tidak Mampu di Pengadilan Agama Purwakarta (Studi pada Layanan Pembebasan Biaya Perkara) Tahun 2017, pada dimensi komunikasi indikator transmisi dapat diupayakan melalui diperbaikinya sistem pemberian informasi yang ramah masyarakat tidak mampu karena ketika yang dikembangkan basis internet, maka masyarakat tidak mampu tetap akan kesulitan untuk menemukan informasi kebijakan tersebut. Pada sumber daya indikator staf dengan ditambahnya kuantitas pegawai Pengadilan Agama (PA) Purwakarta agar tidak terjadi double job, kemudian untuk indikator fasilitas dapat diupayakan dengan meningkatkan fasilitas yang diberikan dari mulai hal sederhana, seperti memperjuangkan anggaran lebih untuk teknis-teknis implementasi kebijakan implementasi kebijakan Peraturan Mahkamah Agung Republik Indonesia Nomor 1 Tahun 2014 tentang Pedoman Pemberian Layanan Hukum Bagi Masyarakat Tidak Mampu di Pengadilan Agama Purwakarta (Studi pada Layanan Pembebasan Biaya Perkara) Tahun 2017 
POLITICON : Jurnal Ilmu Politik Vol.1 No.2 ; Hal 175-192

Website : http://journal.uinsgd.ac.id/index.php/politicon ISSN : 2685-6670 ( Online )

seperti memberikan fasilitas sosialisasi secara langsung kepada masyarakat. Untuk dimensi disposisi dapat diupayakan melalui dimensi sumber daya fasilitas dan harus mengalami evaluasi lebih agar tidak akan menjadi penghalang yang berarti. Kemudian untuk dimensi struktur birokrasi, peningkatan kerjasama diantara pegawai dapat menjadi salah satu upaya untuk mengatasi kendala yang terjadi dan dapat pula dengan melakukan evaluasi yang rutin guna pemeriksaan semua aspek yang mendukung berlangsungnya implementasi kebijakan tersebut.

\section{DAFTAR PUSTAKA}

Alwasyi, F. S. (2019). Implementasi Kebijakan Peraturan Mahkamah Agung Republik Indonesia Nomor 1 Tahun 2014 Tentang Pedoman Pemberian Layanan Hukum Bagi Masyarakat Tidak Mampu Di Pengadilan Agama Purwakarta: Studi Pada Layanan Pembebasan Biaya Perkara Tahun 2017. Uin Sunan Gunung Djati Bandung.

Anggara, A. F. (2018). Strategi Guru Pendidikan Pancasila Dan Kewarganegaraan Dalam Pengembangan Wawasan Global Peserta Didik Berdasarkan Nilai-Nilai Pancasila. E-Civics, 7(2), 174-182.

Anggraini, W. W. (2018). Efektivitas Program Pendidikan Luar Sekolah Dalam Kejar Paket C Di Pusat Kegiatan Belajar Masyarakat "Variant Centre" Kelurahan Petemon Kecamatan Sawahan Kota Surabaya. Jurnal Aplikasi Administrasi, 20(1), 39-51.

Darmawan, D. (2013). Metode Penelitian Kuantitatif. Bandung: Pt Remaja Rosdakarya.

Engkus, E. (2017). The Influence Of Organizational Behavior On Work Ethics Employees In Bandung Regency Goverment. International Academy Of Selence, Engginering And Tecnology, 1(1).

Ishak, D., Maolani, D. Y., \& Engkus, E. (2017). Konsep Kinerja Dalam Studi Organisasi Publik. Jispo: Jurnal Ilmu Sosial Dan Ilmu Politik, 7(2), 101120.

Lele, G. (2012). The Paradox Of Distance In Decentralized Indonesia. Jurnal Ilmu Sosial Dan Ilmu Politik, 15(3), 220-231.

Moleong, L. J. (2011). Metodologi Penelitian Kualitatif, Cetakan Xxix. Bandung: Pt. Remaja, Rosdakarya.

Nazir, M. (2014). Metode Penelitian Cet. 9. Penerbit Ghalia Indonesia. Bogor. 
POLITICON : Jurnal Ilmu Politik Vol.1 No.2 ; Hal 175-192

Website : http://journal.uinsgd.ac.id/index.php/politicon ISSN : 2685-6670 ( Online )

Pn-Purwakarta. (2014). Pelayanan Pembebasan Biaya Perkara Perdata (Prodeo). Retrieved July 1, 2019, From Pn-Purwakarta.Go.Id Website: Http://Www.Pn-Purwakarta.Go.Id/Pelayanan-Pembebasan-BiayaPerkara-Perdata-Prodeo.Html

Sugiyono. (2013). Metode Penelitian Pendidikan Pendekatan Kauntitatif, Kualitatif Dan R\&D. Bandung: Alfabeta. 